\title{
IMPROVING THE LEARNING OUTCOMES OF KNOWLEDGE AND INQUIRY SKILL DOMAIN OF THIRD GRADE STUDENTS AT SMP NEGERI 14 KENDARI USING GUIDED INQUIRY LEARNING MODEL ASSISTED BY SCIENCE KIT
}

\author{
Luh Sukariasih $^{1 *}$, I Gede Purwana Edi Saputra², Fahrudi Ahwan Ikhsan ${ }^{3}$, Andri Estining \\ Sejati $^{4}$, Khaerun Nisa ${ }^{1}$ \\ ${ }^{1}$ Department of Physics Education, Halu Oleo University, Indonesia \\ ${ }^{2}$ Department of Physics Education, Sembilanbelas November Kolaka University, Indonesia \\ ${ }^{3}$ Department of Geography Education, University of Jember, Indonesia \\ ${ }^{4}$ Department of Geography Education, Sembilanbelas November Kolaka University, Indonesia \\ *Email: luhsukariasih@yahoo.com
}

Received 29 March 2019/ Revised 13 August 2019/ Accepted 18 August 2019/ Published 23 August 2019

\begin{abstract}
The study aims to improve the learning outcomes in the field of knowledge and inquiry skill in class VIII 5 SMP Negeri 14 Kendari on the subject matter of light in atmosphere as the effect of applying the guided inquiry learning model assisted by science KIT. The method of the study used a classroom action research with research design is cycle model. The research subject is the students of class VIII 5 SMP Negeri 14 Kendari in the academic year 2016/2017 which consist of 26 students. The learning data achievements of the learners' realm were obtained through the learning result test (cycle test), the skill data of the learners were obtained through the inquiry sheet, and then was analyzed used the descriptive statistics. Results of data analysis are: 1) learning outcomes increased from 60,31 in cycle I to 75 in cycle II; 2) the students group inquiry skill increased form average value 2.68 (enough category) in the cycle I to 3.15 (good category) in cycle II; 3 ) the students mastery learning percentage increase from $42.31 \%$ (11 students) in cycle I to $77 \%$ (20 students) in cycle II. It could be concluded that the implementation of guided inquiry learning model assisted by science KIT could improve the learning outcomes of knowledge and inquiry skill domain on Class VIII 5 SMP Negeri 14 Kendari in the subject matter of light in atmosphere.
\end{abstract}

Keywords: guided inquiry, inquiry skills, learning outcomes,science KIT.

\section{Introduction}

Education science is a branch of science that is built on observation and classification of data, and is usually compiled and verified in quantitative laws, which involve the application of mathematical reasoning and data analysis to natural phenomena. Natural events are included in the study of physical geography. In essence, education science is a science of natural phenomena that is poured in the form of facts, concepts, principles, and laws that are validated and through a series of activities in the scientific method (Depdiknas, 2004). According to Aksa et al. (2019), geography spesification are physical geography, social geography, and technical geography. 
One of physical geography study way through mathematics or counting. This is often feared and tends to be disliked by most students which has an impact on the low level of understanding of teaching material. According to Sohibun (2014), learning with a count is still to understanding in the form of conceptsand formulas.

The results of preliminary observations made on VIII class students in SMP Negeri 14 Kendari on $6^{\text {th }}$ December 2016, found low learning outcomes in the realm of students' knowledge especially in the subject matter of light in atmospherein class VIII 5. This can be seen from the average daily test results obtained by the value of 67.3. 13 out of 23 students (57\%) scored below the Minimum Completion Criteria (68 points) and only 10 students (43\%) completed.

The results of interviews with teachers in class VIII 5 obtained learning outcomes in the realm of students' knowledge more on factual knowledge, while for conceptual knowledge, procedural knowledge, and metacognitive knowledge were only a few that students could understand. Students rarely ask questions in the learning process, meaning that the ability of students to be involved in formulating problems or questions is also lacking. Experimental activities in atmosphere light material that lack make competent skills in this case the skills to carry out experiments, collecting observational data and formulating conclusions are also lacking. According to Anderson \& Krathwohl (2015), the knowledge dimension consists of: four types: factual knowledge, conceptual knowledge, procedural knowledge, and metacognitive knowledge.

The low average learning outcomes of atmosphere light material according to observation and interviews VIII 5 Class SMP Negeri 14 Kendari caused in the learning process the model used by the teacher is teacher centered. Teacher is very active while the students tend to be passive in the learning process which makes learning monotonous and less student participation. This learning process makes it students difficult to understands the material taught by the teacher. Teacher teach less of experiment activities on material that requires experimental activities made students think abstractly about the material. According to Sanjaya (2014), in conventional learning the position of students as objects of learning with the role as recipients of information passively.

The students are only faced with concepts and formulas without any learning activities that demand the full activity of students in understanding the knowledge taught. The learning process at the junior secondary level is still dominated by teachers compared to students with one-way communication especially in the VIII 5 Class SMP Negeri 14 Kendari. This is thought to be one of the factors causing low understanding of subject matter for junior high 
school students. According to Amaliana (2017), in teacher-centeder learning, teachers play important roles in the learning process as information providers or evaluator, and students are viewed as learners who passively receive information.

The solution about the lack of student learning process and outcome is using leaning model. One of learning model that can make students more active and the learning process more interesting is the guided inquiry. The guided inquiry emphasizes students to be active and find their own knowledge. This relates to conceptual knowledge and procedural knowledge is easier to understand if students can find their own knowledge through experiments. A good learning process is that students are more active than teachers, because the learning process like this is more interesting and the material is easier to understand. According to Hidayati et al.(2016), in formulate problems and make hypotheses stages the student become active thinking direcly confronts the issues to be resolved. According to Hardianti \& Kuswanto(2017), learning through inquiry gives learnenrs independence by encouraging them to have a more active and responsible role in various stages of investigation.

Guided inquiry can improve the inquiry skills and students learning outcome. Guided inquiry can more effective if use experimental equipment in the school like science KIT tools. There is science KIT tools in the science laboratory in SMP Negeri 14 Kendari. Based on the analysis of the problem, the teacher obtained the appropriate model to solve the student problem in the class with the guided inquiry learning model assisted by science KIT. According to Greenwald \& Quitadamo (2014), inquiry learning model combine with clinical case namely IBCC in the health matter in the neuro anatomy cursus students learn by using process skills, attitudes, and rational thinking knowledges. According to Kuhlthau et al.(2015), inquiry directly connects between matter and the real world.

Many people think that the light in atmosphere material is quite difficult because some of the sub-material makes students think abstractly so that there is needed for direct activity to finding concepts. The use of guided inquiry learning assisted by science KIT is very suitable in learning atmosphere light material. Guided inquiry learning model is learning that involves all the ability of students to search and investigate systematically and logically so that they can formulate their own findings. Guided inquiry learning will be more effective with practical activities in this case utilizing science KIT.

Application of this model is carried out in two cycles of learning in the classroom to improve learning outcomes in the realm of students' knowledge and skills. Guided inquiry learning model that is a model that emphasizes more on students to actively train courage, 
communicate and try to find their own knowledge to solve problems faced through an experiment with direct guidance by the teacher. The combination of inquiry and science KIT models is very suitable, because this model will make students find their own knowledge through direct activities of students in this case the experiment using science KIT teaching aids. According to Piaget (1970), by using real experience, a person's cognitive development will be better than just using language to communicate. According to Sapriya (2014), guided inquiry learning has the advantage of developing thinking skills, knowledge, attitudes, and values in students compared to the classical approach.

The research by Ahmadi (2015) conducted at SDN 1 Telaga, Gorontalo district showed that learning by using KIT teaching aids in science learning can make students more easily understand the material being taught, and students are more enthusiastic in learning learning. Based on this description, the purpose of this study is to improve learning outcomes in the realm of knowledge and skills in the form of students ofclassVIII 5 of SMP 14 Kendari in learning the subject matter of light in atmosphere through a guided inquiry guided model science KIT.

\section{The Methods}

This study used a type of classroom action research. The research was conducted from 10 May to 24 May 2017 in 2016/2017 academic year with the subject matter of light in atmosphere. The subjects of this study were all students on class VIII 5 in the even semester of SMP Negeri 14 Kendari with 26 students.

The research design is a cycle model. Before each cycle phase is carried out first a preliminary study is carried out. The data in this research were analyzed using descriptive statistics. Determination of the value of the real learning outcomes of students' knowledge of the range of scores used for the description test in this study is 0 to 100 with the formula (Tim Direktorat Pembinaan SMP, 2017).

The average value of learning outcomes in the knowledge class $(\bar{X})$, Standard deviation (SD),\% complete, and categorizing the value of learning outcomes with formula (Sudjana, 2014). Normalized Gain (N-Gain) is an increase in learning outcomes in the realm of students knowledge and skills in the first cycle and second cycle of inquiry are determined using equations from (Riduwan, 2015). N-Gain Criteria $\geq 0.7$ (High), $0.3 \leq \mathrm{N}-$ Gain $>0.7$ (Medium), N-Gain <0.3 (Low). Calculating and classifying the average score of inquirt skills associated with students with formula (Sugiyono, 2014).Below is reseach flow diagram. 


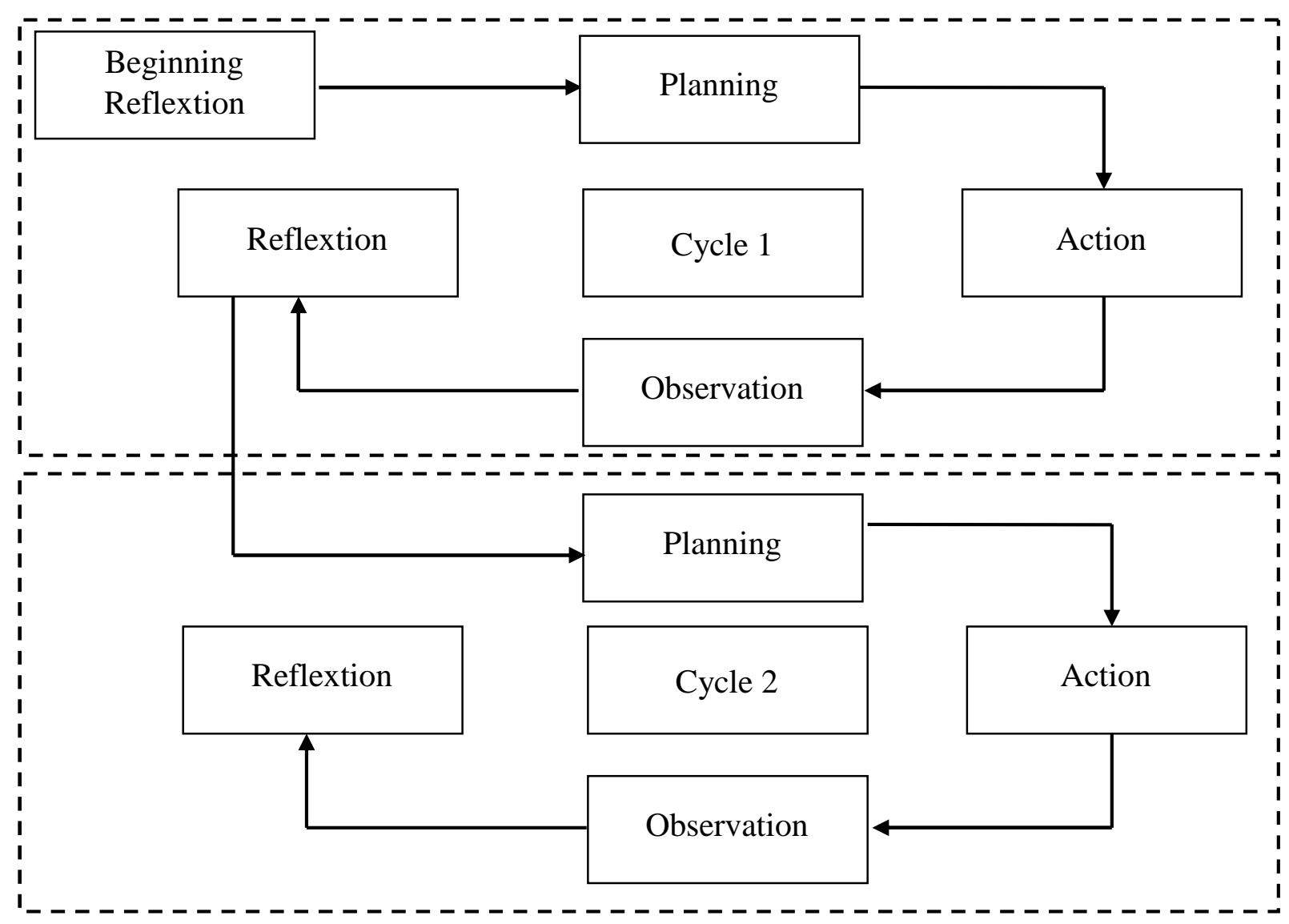

Figure 1. Classroom Action Research Flow Diagram (Arikunto, 2016)

\section{Results and Discussion}

\subsection{Inquiry skills of Student Groups}

The summary of the results of data analysis in the inquiry group skills of students in the teaching-learning process in each cycle can be seen in Table 1.

Table 1. Results of Data Analysis of Inquiry Skills for Student Groups per Cycle

\begin{tabular}{|c|c|c|c|c|c|c|}
\hline \multirow[t]{2}{*}{ No } & \multirow[t]{2}{*}{ Observed aspects } & \multicolumn{4}{|c|}{ the average value of inquiry skills student groups per cycle } & \multirow[t]{2}{*}{ N-Gain } \\
\hline & & CycleI & Categories & cycle II & Categories & \\
\hline 1. & Formulate problems & 2,91 & Satisfactory & 3,12 & Good & 0,19 \\
\hline 2. & Formulate a hypothesis & 2,25 & Satisfactory & 3 & Good & 0,43 \\
\hline 3. & Experiment & 2,67 & Satisfactory & 3,25 & Good & 0,44 \\
\hline 4. & Collecting data & 3,08 & Good & 3,37 & Good & 0,32 \\
\hline 5. & Formulating conclusions & 2,5 & Satisfactory & 3 & Good & 0,33 \\
\hline \multicolumn{2}{|c|}{$\begin{array}{l}\text { the average value of inquiry } \\
\text { skills in groups of students }\end{array}$} & \multicolumn{2}{|c|}{2,68} & \multicolumn{2}{|c|}{3,15} & 0,34 \\
\hline & Categories & \multicolumn{2}{|c|}{ Satisfactory } & \multicolumn{2}{|c|}{ Good } & Medium \\
\hline
\end{tabular}

Resources:Riduwan (2015), Sanjaya (2014), Sugiyono (2014)

Based on Table 1, it can be seen that in the first cycle there were four aspects of inquiry skills in groups of students who obtained an average value with satisfactory 
categories, namely aspects of formulating problems, aspects of formulating hypotheses, aspects of conducting experiments and aspects of formulating conclusions. This shows that in the first cycle, the skills of the inquiry group of students was not optimal.

In the second cycle the skills of inquiry students groups in each aspect had increased. The lowest average value of inquiry group skills of students in the cicle I, that's mean the aspect of formulating a hypothesis increases in the second cycle to 0.75 . While the average value of inquiry skills in the highest students group in the first cycle, that's mean the aspect of collecting data increased by cycle II to 0.29 . In the second cycle of the 5 aspects of inquiry skills the observed group of students had an average score of 3.15 which good categorized.

The average value of inquiry group skills in the first cycle and second cycle can be seen in Table 1. From the table, the increase in student inquiry skills is shown by the average $\mathrm{N}$-Gain which is categorized as a moderate increase and the average value of inquiry skills group of students experienced an increase of 0.47 .

\subsection{Teacher Activity}

An overview of teacher activities in managing learning using a guided inkuri learning model assisted by science KIT, teacher activities in each cycle can be seen in Table 2.

Table2.Results of Data Analysis of Teacher Activities on Each Cycle

\begin{tabular}{|c|c|c|c|}
\hline \multirow{2}{*}{ No } & \multirow{2}{*}{ Aspects observed } & \multicolumn{2}{|c|}{ Value Average } \\
\hline & & Cycle I & Cycle II \\
\hline A. & Introduction & & \\
\hline 1 & Opening the lessons and check the readiness of students & 4 & 4 \\
\hline 2 & Give apperception to students & 3 & 4 \\
\hline 3 & Deliver/write down topics and learning objectives. & 3 & 3 \\
\hline \multicolumn{4}{|c|}{ B. Main Activity } \\
\hline 4 & Presenting problems so students can formulate problems & 4 & 4 \\
\hline 5 & $\begin{array}{l}\text { Direct students to gather information according to what they see } \\
\text { at the stage of presenting the problem }\end{array}$ & 3 & 4 \\
\hline 6 & Direct students to get information through experiments & 2,5 & 3 \\
\hline 7 & $\begin{array}{l}\text { Direct students to formulate explanations based on the results of } \\
\text { the experiment }\end{array}$ & 2,5 & 3 \\
\hline 8 & $\begin{array}{l}\text { Direct students to analyze experimental data in the form of } \\
\text { conclusions }\end{array}$ & 3 & 4 \\
\hline \multicolumn{4}{|c|}{ C. $\quad$ Post Activity } \\
\hline 9 & Conclusion on the results of the activity & 2,5 & 4 \\
\hline 10 & The teacher informs the material for the next meeting & 3 & 3 \\
\hline \multicolumn{4}{|c|}{ D. Class Atmosfer } \\
\hline 11 & Enthusiastic students & 2,5 & 3 \\
\hline 12 & Enthusiastic Teacher & 3 & 3 \\
\hline 13 & Time according to allocation & 3 & 4 \\
\hline 14 & $\mathrm{KBM}$ according to RPP & 2,5 & 3 \\
\hline \multicolumn{2}{|r|}{ Average Value } & 2,9 & 3,5 \\
\hline \multicolumn{2}{|r|}{ Category } & Enough & Good \\
\hline
\end{tabular}


Resousces: Sanjaya (2014), Sugiyono (2014)

Based on Table 2 it can be seen that in the first cycle the average value of the teacher' lowest activity was the activity of the teacher directing students to obtain information through experiments, directing students to formulate explanations based on the results of the experiment and the conclusion of the results of the activity. While the highest teacher activity in the first cycle was when opening lessons and checking the readiness of students and presenting problems so that students can formulate problems.

In the second cycle, it was seen that every aspect observed was maintained and experienced an increase. One aspect of teacher activity with the lowest average value in cycle I is that the teacher directs students to obtain information through experiments increasing in the second cycle of 0.5 . In addition, the lowest average value of other teacher activities in the first cycle is the conclusion of the results of increased activities in the second cycle of 1.5 . Table 2, shows an increase in teacher activity from cycle I to cycle II where the average value of teacher activity has increased by 0.6 .

\subsection{Learning Outcomes of Students Knowledge}

Data on the realm learning outcomes of students' knowledge is obtained by using learning outcomes tests. Based on the descriptive analysis of the learning outcomes of the realm of students 'knowledge on the subject matter of atmosphere light shown in the form of cycle tests consisting of cycle I tests and cycle II tests, a summary of the results of data analysis of the learning outcomes of students' knowledge per cycle is as follows.

Table 3.Learning Outcomes Data Analysis Results of Student Knowledge Sphere Per Cycle

\begin{tabular}{|c|c|c|c|c|}
\hline \multirow{2}{*}{ No. } & \multirow{2}{*}{ Value } & \multicolumn{2}{|c|}{ Cycle } & \multirow{2}{*}{ N-Gain } \\
\hline & & I & II & \\
\hline 1 & Minimum & 20 & 22 & $-0,272$ \\
\hline 2 & Maximum & 78 & 95 & 0,785 \\
\hline 3 & Average & 60,31 & 75 & 0,345 \\
\hline 4 & Deviation Standard & 17,26 & 14 & 0,254 \\
\hline \multicolumn{2}{|r|}{ Amount of Completion } & 11 & 20 & - \\
\hline \multicolumn{2}{|r|}{ Amount of incomplete } & 15 & 6 & - \\
\hline \multicolumn{2}{|r|}{$\%$ Complete } & 42,31 & 77 & - \\
\hline \multicolumn{2}{|r|}{$\%$ Incomplee } & 57,69 & 23 & - \\
\hline
\end{tabular}

Resources: Riduwan ( 2015), Sudjana (2014) Tim Direktorat Pembinaan SMP (2017)

From Table 3 above, it can be seen that the knowledge learning outcomes of VIII5 students of SMP Negeri 14 Kendari on the subject matter of atmosphere light learning 
through the application of a guided inquiry learning model assisted by science KIT indicate an increase from cycle I to cycle II. This is seen in the value of the average learning outcomes in the realm of knowledge increasing from cycle I to cycle II, it can be seen from the average $\mathrm{N}-$ Gain of 0.345 in the medium category.

The percentage of learning completeness from cycle I increased to cycle II to be above $75 \%$ who had achieved KKM, showing completeness classically from classroom action research has been fulfilled which means that the model of guided inquiry teaching assisted by science KIT can solve learning problems of VIII5 students in SMP Negeri 14 Kendari.

\subsection{Cycle I}

The results showed that in the first cycle there were still some aspects of the skills of the inquiry group of students that needed to be improved. The skills of inquiry groups of students who are still lacking and need to be improved are in the aspects of formulating problems, formulating hypotheses, conducting experiments and formulating conclusions. This is because students are not used to formulating problems, formulating hypotheses and formulating conclusions with learning models with the help of applied science KIT. The low average value of group inquiry skills is influenced also by the teacher who still lacks directing students in conducting experiments and formulating conclusions during the learning process. The average value of the problem formulation is higher than the average value of the aspects of formulating the hypothesis, this is due to students' initial knowledge of the concepts related to the material in presenting problems that are still lacking so that students have difficulty when formulating hypotheses. According to Hidayati et al. (2017), teachers should be able to prepare the questions about the problem problem is close to student environment.

In the first cycle based on descriptive analysis, the teacher's activity shows the average value of teacher activity in a sufficient category. Where teacher activity is still quite based on. Table 2 of which is the teacher is still lacking in directing students to obtain information through experiments, directing students to formulate explanations based on the results of the experiment and formulating conclusions on the results of the activities.

Based on the results of reflection on teacher activity, by knowing the shortcomings in the first cycle, the teacher improved the way to teach learning material in accordance with the guided inquiry learning model assisted by science KIT, so that it was expected that in the next meeting an increase in teacher activity. According to Sitorus et al. (2017), in guided learning teacher can manage and implement a learning to students which contains scientific steps. 
Based on the first problem, namely how to improve the learning outcomes of knowledge in class VIII5 SMP Negeri 14 Kendari as the effect of applying a guided inquiry learning model assisted by science KIT on the subject matter of light in atmosphere, it can be explained that based on the results of descriptive analysis of learning outcomes in the knowledge domain each cycle tends to increase towards the better. According to Zaini (2016), there is a significant effect that is given by using guided inquiry based learning with the cognitive process learning outcome.

The percentage of completeness in this first cycle has not yet reached the research target, which is to achieve learning completeness in a classical minimum of $75 \%$. This is because students have not been able to recall the material being taught, besides that students pay less attention and listen to the initial problems conveyed by the teacher, students are not accustomed to formulating conclusions, and during the experiment the students are less cooperative with their group friends. In addition, the teacher is not optimal in delivering direction and guidance to students in conducting experiments and formulating explanations in the form of conclusions so that students experience obstacles to conducting experiments and formulating conclusions on the results of experiments. According to Wardani et al. (2015), cooperation can be increased through guided inquiry learning.

After analyzing and reflecting on the first cycle, the teacher in this case the researcher and observer make improvements in learning through guided inquiry learning assisted by science KIT to be applied in the second cycle, so that the realm of learning outcomes of knowledge of VIII5 students in SMP Negeri 14 Kendari can increase as expected in cycle II.

\subsection{Cycle II}

From the results of the descriptive analysis of the skills of inquiry groups of students in the second cycle showed an increase in the skills of inquiry groups of students from cycle I. This is as shown in Table 1, the average skill scores of groups in the second cycle were 3.15 by category well. The skills aspect of inquiry groups in the second cycle on average experienced an increase from the first cycle. Improving the skills of the best group inquiry inquiry was on the aspect of formulating a hypothesis, where the aspect of formulating this hypothesis increased by 0.75 higher than the increase in other aspects of inquiry skills. . This is because students are getting used to formulating hypotheses, assisted by teachers with clearer direction and presenting clearer problems also in the learning process using a guided inquiry learning model assisted by science KIT. According to Sarwi\&Prayitno (2016), there is 
a significant application of guided learning model to the students inquiry 'understanding of the concept and being able to improve practice in inquiry syntax.

The inquiry process is characterized by the presentation of problems that can be solved in groups through experiments that develop ideas and thoughts and activities centered on problem solving skills. In this learning model students make questions that guide the next investigation, including activities to form hypotheses, carry out experiments, collect experimental data, and formulate conclusions experiments. The teacher acts as a facilitator. The increase in the average value of the inquiry group skills indicates that the weaknesses or weaknesses found in the first cycle can be overcome so that the skills of the inquiry group of students are obtained as expected. According to Putra et al. (2016) the application of guided inquiry trains students to pass the learning syntax well and is able to improve students science literary skills.

In the second cycle the teaching activity of the teacher showed a significant increase, where in the second cycle the average value of the teacher's activity obtained an average value of 3.5 which was categorized as good. The results of the analysis and observations in the second cycle showed an increase in teacher activity by implementing a guided inquiry learning model assisted by science KIT. Increasing the average value of teacher activity indicates that the weaknesses contained in the first cycle can be overcome so that the teacher can manage learning using a guided inquiry learning model assisted by science KIT. According to Niana et al.(2016), the teacher's activities in applying the guided inquiry model were able to improve student learning success.

From the results of descriptive analysis of the learning outcomes of the realm of students' knowledge shows an increase in learning outcomes in the realm of knowledge from cycle I to cycle II. This can be seen with the average value obtained by students in the first cycle increased in the second cycle. Improving the learning outcomes of the students 'knowledge in the second cycle showed an increase in students' mastery of learning material and the motivation of students to attend learning until the last meeting. According to Mulyana et al. (2018), there is a significant influence guided Inquiry learning the student learning result.

The increase in learning outcomes is also because the teacher has been able to manage the learning process, besides that students are also familiar with the guided inqury learning model assisted by science KIT in the learning process, because in the guided inquiry learning model assisted by science KIT students can observe directly the concepts that are taught by conducting experiments and can be more creative looking for answers to the problems given. 
So that students are not difficult to understand the concept of science, especially in the subject matter of atmosphere light and relate it to their experience in everyday life. According to Yewang et al. (2016) guided inquiry is better than free inquiry in guiding students in investigations, observations and hypothesestests.

\section{Conclusion}

The conclusion in this study is the application of a guided inquiry learning model assisted by science KIT can improve learning outcomes in the aspect of knowledge, skills and learning completeness of students of Class VIII 5 of SMP Negeri 14 Kendari on the subject matter of atmosphere light. This conclusion is supported by several specific conclusions of the results of descriptive empirical data analysis as follows.

a. The skills of inquiry in groups of VIII 5 students in SMP Negeri 14 Kendari through the assisted guided inquiry learning model of KIT IPA have increased. This can be seen from the average value of the skills aspects of the inquiry group of students in the first cycle and second cycle. Where in the first cycle obtained an average value of 2.68 sufficient categories, increased in the second cycle to 3.15 good categories.

b. The realm of learning outcomes of knowledge of Grade VIII 5 students of SMP Negeri 14 Kendari who learned through assisted guided inquiry learning model KIT IPA increased from the first cycle to the second cycle which was indicated by the average value of the realm learning outcomes of students' knowledge increased from 60.31 to 75 , the standard deviation decreased from 17.26 to 14 and the average N-Gain was 0.34 medium category.

c. The learning completeness of Grade VIII 5 students of SMP Negeri 14 Kendari who learned through a guided inquiry learning model assisted by science KIT showed that there was an increase in the percentage of learning completeness from cycle I to cycle II, in the first cycle the completeness percentage was $42.31 \%$ or 11 students had reached minimum completeness criteriaand in cycle II the percentage of completeness increased to $77 \%$ or 20 students had reached.

\section{References}

Ahmadi, L. (2015). Pemanfaatan Alat KIT pada Pembelajaran.Gorontalo: Universitas Negeri Gorontalo.

Aksa, F.I., Utaya, S., \& Bachri, S. (2019). Geografi dalam Perspektif Filsafat Ilmu. Majalah Geografi Indonesia,33(1), 43-37. 
Amaliana, I. (2017). Teacher-centered or Student-centered Learning Approach to Promote Learning?. Jurnal Sosial Humaniora, 10(2), 59-70.

Anderson, L.W., \& Krathwohl, D.R. (2015). Kerangka Landasan untuk Pembelajaran, Pengajaran, dan Asesmen Revisi Taksonomi Pendidikan Bloom (A. Priantoro, Trans.). Yogyakarta: Pustaka Pelajar.

Arikunto, S. (2016). Prosedur Penelitian Suatu Pendekatan Praktik. Jakarta: Rineka Cipta.

Depdiknas. (2004). Kurikulum Mata PelajaranSains SMP danMTs.Jakarta: Depdiknas.

Greenwald, R.R.,\&Quitadamo, I.J. (2014). A Mind of Their Own: Using Inquiry-based Teaching to Build Critical Thinking Skills and Intellectual Engagement in an Undergraduate Neuroanatomy Course. The Journal of Undergraduate Neuroscience Education, 12(2), 100-106.

Hardianti, T., \& Kuswanto, H. (2017). Difference among Levels of Inquiry: Process Skills Improvement at Senior High School in Indonesia. International Journal of Instruction, 10(2), 119-130.

Hidayati, D.N., Amaluddin, L.O., \& Surdin. (2016). The Effect Guided Inquiry to Critical Thinking Ability to Build Student Character in Geography Subject. Social Science, Education and Humanities Research,9(1), 367-371.

Kuhlthau, C.C., Maniotes, L.K., \& Caspari, A.K. (2015). Guided Inquiry: Learning In The 21 st Century(2nd ed.). California: Libraries Unlimeted.

Mulyana, S., Rusdi, \& Vivanti, D. (2018). The Effect of Guided Inquiry Learning Model and Scientific Performance on Student Learning Outcome. Indonesian Journal of Science and Education, 2(1), 105-109.

Niana, R., Sarwanto, \& Ekawati, E.Y. (2016). The Application of Guided Inquiry Model on Physic Learning to Improve Scientific Attitude and Students Analysis Ability. Proceedings of the 2nd International Conference on Teacher Training and Education Sebelas Maret University,2(1), 605-615.

Piaget, J. (1970). Science of Education and the Psychology of The Child. New York: Wiley.

Putra, M.I.S., Widodo, W., \& Jatmiko, B. (2016). The Development of Guided Inquiry Science Learning Materials to Improve Science Literacy Skill of Prospective MI Teachers.JPII, 5(1), 83-93.

Riduwan. (2015). Dasar-Dasar Statistika. Bandung: Tarsito.

Sanjaya, W. (2014). Strategi Pembelajaran. Jakarta: Kencana Prenada Media Group.

Sapriya. (2014). Pendidikan IPS. Bandung: RemajaRosdaKarya.

Sarwi, S.,\& Prayitno, W.W. (2016). Implementation of Guided Inquiry Physics Instruction to Increase An Understanding Concept and to Develop The Students Character Conservation. JurnalPendidikanFisika Indonesia,12(1), 1-7. 
Sitorus, H.H., Hasruddin, \& Edi, S. (2017). The Influence of Inquiry Learning Model on Student's Scientific Attitudes in Ecosystem Topic at MTs. Daarul Hikmah Sei Alim (Islamic Junior High School) Asahan. International Journal of Humanities Social Sciences and Education (IJHSSE), 4(11), 170-175.

Sohibun. (2014). Penerapan Strategi Belajar Dengar Lihat Kerjakan (Delikan) Berbasis Laboratorium Mini terhadap Ketrampilan Proses Sains (KPS) Siswa SMA Kelas X MIA. Jurnal Imliah Edu Research, 3(1), 53-67.

Sudjana, N. (2014). Penelitian Hasil Proses Belajar Mengajar. Bandung: Remaja Rosdakarya.

Sugiyono. (2014). Metode Penelitian Pendidikan Pendekatan Kuantitatif, Kualitatif, dan $R \& D$. Bandung: Alfabeta.

Tim Direktorat Pembinaan SMP. (2017). Panduan Penilaian oleh Pendidik dan Satuan Pendidikan Sekolah Menengah Pertama. Jakarta: Kementerian Pendidikan dan Kebudayaan Direktorat Jenderal Pendidikan Dasar dan Menengah Direktorat Pembinaan Sekolah Menengah Pertama.

Wardani, S., Nurhayati, S., \& Safitri, A. (2015). The Effectiveness of the Guided Inquiry Learning Module towards Students' Character and Concept Understanding. International Journal of Science and Research (IJSR), 5(6), 1589-1594.

Yewang, M.U.K., Degeng, I.N.S., Setyosari, P., \& Sulton. (2016). The Effect of Guided Inquiry Learning Method VS Free Inquiry Against Learning Outcomes. International Conference on EducationUM, 561-568.

Zaini, M. (2016). Guided Inquiry Based Learning on the Concept of Ecosystem Toward Learning Outcomes and Critical Thinking Skills of High School Student. IOSR Journal of Research \& Method in Education (IOSR-JRME), 6(6), 50-55. 